\author{
Paulina LegutKo-Kobus ${ }^{1}$
}

\title{
Programowanie rozwoju w skali regionalnej i lokalnej - doświadczenia i wyzwania w perspektywie nowego okresu programowania 2014-2020 i konferencji Rio+20
}

\section{Wprowadzenie}

Szczyt Ziemi w Rio de Janeiro w 1992 roku wprowadził zasadę rozwoju zrównoważonego do polityki - w tym regionalnej i lokalnej, 20 lat później także w Rio podkreślono korelacje z milenijnymi celami rozwoju, a także potrzebę uwzględniania i integrowania trzech podstawowych filarów rozwoju zrównoważonego (społecznego, gospodarczego i przyrodniczego). Doświadczenie 20 lat implementacji rozwoju zrównoważonego do procesów programowania pozwala na dokonywanie podsumowań i wskazanie, jaki powinien być docelowy model programowania rozwoju zgodny z wyzwaniami współczesnego rozwoju społeczno-gospodarczego i głównymi wyzwaniami Unii Europejskiej. Kluczowy dokument, czyli Strategia Europa $2020,{ }^{2}$ zakłada, że dzięki wspólnemu działaniu państw członkowskich nastąpi przyspieszenie wyjścia z kryzysu gospodarczego, a ,gospodarka UE stanie się inteligentna i zrównoważona, będzie sprzyjać włączeniu społecznemu, będzie się mogła pochwalić wysokimi wskaźnikami zatrudnienia i wydajności oraz większą spójnością społeczną". Z kolei w dokumencie końcowym konferencji Rio+20 (The Future We Want $^{3}$ ) podkreślono szczególne znaczenie partnerstwa na rzecz wdrażania rozwoju zrównoważonego.

\section{Programowanie rozwoju zrównoważonego w ujęciu teoretycznym}

Od czasu konferencji pod nazwą Szczyt Ziemi, za podstawową zasadę rozwoju i programowania uznaje się rozwój zrównoważony. Zgodnie z zapisem ustawy

1 Szkoła Główna Handlowa

2 Komunikat Komisji, Europa 2020. Strategia na rzecz inteligentnego i zrównoważonego rozwoju sprzyjającego włączeniu społecznemu, Bruksela, 3.3.2010, KOM(2010) 2020 wersja ostateczna, http://ec.europa.eu/eu2020/ pdf/1_PL_ACT_part1_v1.pdf (dostęp na 20.04.2013).

3 http://sustainabledevelopment.un.org/futurewewant.html (dostęp na 20.04.2013). 
prawo ochrony środowiska jest to rozwój spoteczno-gospodarczy, w którym następuje proces integrowania działań politycznych, gospodarczych $i$ społecznych z zachowaniem równowagi przyrodniczej oraz trwałości podstawowych procesów przyrodniczych, aby zagwarantować możliwości zaspokajania podstawowych potrzeb poszczególnych społeczności lub obywateli tak wspótczesnego, jak i przyszłych pokolen. ${ }^{4}$ Uwzględniając zasadę rozwoju zrównoważonego programowanie rozwoju powinno więc $\mathrm{z}$ jednej strony zapewniać osiąganie ładu zintegrowanego, $\mathrm{z}$ drugiej zaś w samym procesie programowania powinny być uwzględnione zasady rozwoju zrównoważonego.

Programowanie rozwoju regionu czy gminy to perspektywa długookresowa. Jest to więc wyznaczenie kursu, ścieżki pozwalającej osiągnąć satysfakcjonujący stan rozwoju danej jednostki samorządu terytorialnego (JST) w perspektywie kilku lub kilkunastu lat, mając na względzie także zapewnienie rozwoju zrównoważonego. Jak podkreśla T. Kudłacz, programowanie rozwoju jest możliwe dzięki opracowaniu kompleksowych, wewnętrznie zgodnych zadań niezbędnych do osiągnięcia przyszłych celów społeczno-gospodarczych. Programowanie to także przyporządkowanie niezbędnych środków i metod realizacji. ${ }^{5}$

Na kanwie idei rozwoju zrównoważonego rodzi się więc pytanie, jak JST mogą programować swój rozwój? Zarówno samorząd gminny, jak i wojewódzki zadania do realizacji wskazuje w podstawowych dokumentach strategicznych, przypisując im hierarchię, następstwa, czas realizacji i potrzebne środki finansowe. Ponieważ programowanie dotyczy przyszłości, to powinno także zawierać element przystosowania do dynamicznie zmieniających się warunków otoczenia (jest to korygująca funkcja programowania). Dlatego też współczesne programowanie rozwoju jest procesem otwartym, monitorowanym oraz wykorzystującym wyniki badań ewaluacyjnych. Niezmiernie ważne jest także włączenie w proces programowania wszystkich aktorów życia społeczno-gospodarczego, tak, żeby już na etapie projektowania każdy z beneficjentów procesu rozwoju mógł określić swoje oczekiwania i mieć wpływ na wybór ścieżki dojścia do satysfakcjonującego stanu rozwoju.

Przystępując do analizy programowania rozwoju w skali regionalnej i lokalnej na kanwie literatury przedmiotu i uwarunkowań prawnych warto zwrócić uwagę na pewne odmienności, związane $\mathrm{z}$ tworzeniem dokumentów programowania $\mathrm{w}$ regionie i w gminie.

Pierwsza odmienność dotyczy ram czasowych - regiony (województwa) w obecnym kształcie zostały utworzone z dniem 1 stycznia 1999 roku. Oznacza to, iż od tego czasu $\mathrm{w}$ regionach powstawał jednolity system programowania, oparty 
Programowanie rozwoju w skali regionalnej i lokalnej - doświadczenia i wyzwania...

przede wszystkim o nadrzędny, kompleksowy dokument, czyli strategię rozwoju. Zgodnie z zapisami ustawy z dnia 5 czerwca 1998 r. o samorządzie województwa ${ }^{6}$ do zadań samorządu województwa należy przygotowanie strategii rozwoju województwa, która powinna uwzględniać następujące cele:

- pielęgnowanie polskości oraz rozwój i kształtowanie świadomości narodowej, obywatelskiej i kulturowej mieszkańców, a także pielęgnowanie i rozwijanie tożsamości lokalnej,

- pobudzanie aktywności gospodarczej,

- podnoszenie poziomu konkurencyjności i innowacyjności gospodarki województwa,

- zachowanie wartości środowiska kulturowego i przyrodniczego przy uwzględnieniu potrzeb przyszłych pokoleń,

- kształtowanie i utrzymanie ładu przestrzennego.

Samorządy gminne działając na mocy ustawy z dnia 8 marca 1990 r. o samorządzie gminnym realizacją m.in. zadania związane z zaspokajaniem zbiorowych potrzeb wspólnoty, czyli tzw. zadania własne gminy, obejmujące grupy problemów takich jak m.in.: ład przestrzenny, infrastrukturę drogową i komunalną, ochronę środowiska i przyrody, ochronę zdrowia, edukację, utrzymanie gminnych obiektów użyteczności publicznej, czy też współpracę ze społecznością lokalną, organizacjami pozarządowymi i upowszechnianie idei samorządności. ${ }^{7}$

Realizacja zadań związanych z prowadzeniem polityki rozwoju, zarówno w skali regionu, jak i gminy jest wieloetapowa, stąd istnieje potrzeba programowania i konsekwentnej realizacji zaprogramowanych zamierzeń, mających docelowo doprowadzić do realizacji wizji rozwoju.

\section{Dotychczasowe doświadczenia z zakresu programowania}

Okres, którego dotyczy niniejsze opracowanie (lata 1992-2012), charakteryzuje niezwykła dynamika podejścia do programowania rozwoju. Ponieważ te 20 analizowanych lat przypada na bardzo różny okres pod względem przemian społecznogospodarczych i politycznych, to dla czytelności analizy wyróżniono kilka etapów:

- etap pierwszy trwający do roku 1998, można go nazwać okresem zafascynowania ideą rozwoju zrównoważonego i lokalności,

- etap drugi to lata 1999-2004, czyli okres porządkowania formalnego programowania i przygotowanie do członkostwa w UE, 
- etap trzeci obejmuje lata od 2004 do 2013, czyli okres od akcesji do UE obejmujący perspektywę programowania i finansowania.

Pierwszy etap, czyli lata od 1992 roku do końca 1998 (czyli do wprowadzenia reformy administracyjnej), to etap tworzenia dokumentów programowania szczególnie w skali lokalnej (gminnej), choć powstawały także dokumenty dla euroregionów (np. dla Euroregionu Bug), ${ }^{8}$ czy województw (ale w układzie 49 jednostek).

W skali gminnej powstawały przede wszystkim Agendy 21, monografie przyrodnicze, inwentaryzacje przyrodnicze czy koncepcje ekorozwoju, a pod koniec lat dziewięćdziesiątych XX w., także strategie rozwoju. Wszystkie te dokumenty cechowało przede wszystkim szczegółowe ujęcie kwestii przyrodniczych i społecznych oraz skupienie się raczej na diagnozie niż wizjach rozwoju. Trudno jednak nie doceniać dokumentów tworzonych w tym czasie, ponieważ z jednej strony stanowiły doskonałe źródło wiedzy o lokalnych uwarunkowaniach rozwoju (w tym także bazę do porównań w latach późniejszych), z drugiej zaś budowały podstawy tożsamości lokalnej opartej o wiedzę z zakresu historii, kultury i przyrody.

Od roku 1994, kiedy to wchodzi w życie ustawa o planowaniu przestrzennym, powstają także nowe dokumenty planistyczne dla gmin, w tym: studium uwarunkowań i kierunków zagospodarowania przestrzennego i plan miejscowy (oba dokumenty sporządzane są dla całego obszaru gminy, w granicach administracyjnych).

Drugi etap, czyli lata 1999-2004, to okres, kiedy programowanie rozwoju staje się podstawą prowadzenia polityki regionalnej. W skali regionalnej (wojewódzkiej) strategia staje się więc pierwszym, kompleksowym dokumentem opracowanym dla nowych województw. Pierwsza edycja strategii powstaje w roku 2000, jedynie strategia rozwoju województwa mazowieckiego uchwalona zostaje w styczniu 2001 roku. Na ten okres przypada także przygotowanie do członkostwa w Unii Europejskiej i korzystanie z pomocy przedakcesyjnej, tym samym potrzeba wykazania, iż planowane do realizacji przedsięwzięcia wpisują się $\mathrm{w}$ wieloletnie plany rozwojowe regionów i gmin. W tym okresie powstaje więc także wiele lokalnych strategii rozwoju, a wymogiem przy ich opracowaniu staje się coraz szersza partycypacja społeczna. Strategia w skali regionalnej jest sporządzana jako dokument obligatoryjny, natomiast w skali lokalnej jest to dokument fakultatywny, ale wymagany często do aplikowania o środki UE. W efekcie takiego podejścia strategie lokalne w tym okresie powstają nader często jako „załączniki do wniosków finansowych”, a nie zapis rzeczywistych wizji rozwojowych i celów do ich osiągnięcia.

Trzeci etap rozpatrywany w niniejszym opracowaniu to okres funkcjonowania w UE. Stając się, w maju 2004 roku, krajem UE weszliśmy w trwający okres pro- 
gramowania 2000-2006. Dwa lata, jakie pozostały do jego zakończenia, stwarzały możliwości korzystania ze środków finansowych na projekty prorozwojowe, ale zaprogramowane. Stąd też gminy, które do tej pory nie opracowywały strategii rozwoju, stanęły przed koniecznością określenia swoich priorytetów rozwojowych albo w strategii, albo też w niezmiernie popularnym po roku 2004 dokumencie, jakim był Plan rozwoju lokalnego (nazywany czasem krótkookresową strategią).

Po roku 2004 ukształtował się obecnie obowiązujący system programowania rozwoju, zarówno w gminie, jak i regionie, który ogólnie dokumenty programowania dzieli na: kompleksowe (odnoszące się do całości procesów rozwojowych) i sektorowe (dotyczące wybranej sfery rozwoju). Najważniejszym kompleksowym dokumentem programowania rozwoju jest zarówno dla gminy, jak i regionu strategia. Dokumenty sektorowe to m.in.:

- dokumenty planistyczne: studium uwarunkowań i kierunków zagospodarowania przestrzennego gminy, plan miejscowy (dla obu sporządzana jest prognoza oddziaływania na środowisko), plan zagospodarowania przestrzennego województwa,

- dokumenty związane z realizacją polityki ekologicznej (w regionie i gminie): program ochrony środowiska, plan gospodarki odpadami,

- inne: opracowanie ekofizjograficzne, inwentaryzacja przyrodnicza, opracowanie ekorozwojowe, strategie sektorowe (np. agroturystyki, alternatywnych źródeł energii, marki terytorialnej, innowacyjności itp.), plany odnowy miejscowości itp.

Okres funkcjonowania w UE, szczególnie pierwszy pełny okres programowania, czyli lata 2007-2013 charakteryzuje także próba oceny systemu programowania w kontekście jego aktualności i hierarchiczności. Zręby potrzebnych zmian i założenia nowego modelu zarządzania strategicznego, w tym programowania, zostały przedstawione przez Ministerstwo Rozwoju Regionalnego w roku 2009 w dokumencie Założenia systemu zarządzania rozwojem Polski. ${ }^{9}$ Zgodnie z dokonaną w nim diagnozą podstawowe mankamenty systemu zarządzania strategicznego rozwojem, w tym programowania, związane były z:

- brakiem spójnej wizji systemu programowania (w tym brakiem koordynacji),

- oderwaniem planowania przestrzennego od społeczno-gospodarczego,

- brakiem wyodrębnionej polityki miejskiej, www.mrr.gov.pl/rozwoj_regionalny/Polityka_rozwoju/System_zarzadzania_rozwojem/Documents/Zalozenia_ SZR_wersja_przyjeta_przez_RM_270409.pdf (dostęp na 25.09. 2012). 
- brakiem ciągłości prac programowych (co wynikało ze zmian sytuacji politycznej).

Te zdiagnozowane w skali kraju mankamenty znajdowały swoje odzwierciedlenie zarówno w skali regionalnej, jak i lokalnej. Dlatego też istotnym z punktu wiedzenia omawianej tematyki jest wskazanie, jak docelowo ma wyglądać system proponowany przez MRR i jakie to będzie miało konsekwencje dla programowania rozwoju regionalnego i lokalnego. Należy bowiem nadmienić, iż w roku 2009 została znowelizowana ustawa o zasadach prowadzenia polityki rozwoju. ${ }^{10}$ Zgodnie z zapisami art. 2. ustawy polityka rozwoju jest zespołem wzajemnie powiązanych działań mających na celu: trwały i zrównoważony rozwój kraju, spójność społeczno-gospodarczą regionalną i przestrzenną, podnoszenie konkurencyjności gospodarki oraz tworzenie nowych miejsc pracy. Za prowadzenie polityki rozwoju odpowiada Rada Ministrów, samorząd województwa, a także samorząd powiatowy i gminny, zaś podstawą prowadzenia polityki rozwoju w skali kraju, regionu i lokalnej jest strategia.

Zaproponowany przez MRR model porządkuje dokumenty, które stanowią podstawę dla strategii regionalnych i lokalnych oraz wyznacza ich horyzonty czasowe. Docelowo w systemie programowania założono cztery kategorie dokumentów o różnym horyzoncie czasowym. ${ }^{11}$

Pierwsza kategoria to horyzontalne, długookresowe strategie opracowywane z uwzględnieniem horyzontu czasowego co najmniej 15 lat (Długookresowa strategia rozwoju kraju - DSRK).

Drugą kategorię stanowią dokumenty horyzontalne średniookresowe sporządzane na okres 4-10 lat - należy do nich Średniookresowa strategia rozwoju kraju (ŚSRK) oraz Krajowa strategia rozwoju regionalnego (KSRR).

Trzecia, najistotniejsza dla omawianego tematu, kategoria dokumentów to inne strategie rozwoju opracowywane przez administrację rządową szczebla centralnego (np. strategie sektorowe, dziedzinowe, ponadregionalne wynikające z celów ŚSRK, nie wykraczające poza jej horyzont czasowy) oraz strategie sporządzane przez jednostki samorządu terytorialnego, w tym strategie wojewódzkie (ich horyzont czasowy nie powinien wykraczać poza ŚSRK).

Czwartą kategorię stanowią dokumenty operacyjne, narzędziowe, czyli programy, poprzez które będzie następowała realizacja strategii.

Ustawa z dnia 6 grudnia 2006 r. o zasadach prowadzenia polityki rozwoju (t.j. Dz.U. Nr 84, poz. 712, z późn. zm.).

Nowy model zarządzania strategicznego w Polsce, materiał szkoleniowy cz. 1., MRR, Warszawa, 2012, s. 12. 
Planowanie społeczno-gospodarcze ma mieć także wymiar przestrzenny, dlatego też podkreśla się w dokumentach MRR, iż DSRK ma być spójna z Koncepcją Przestrzennego Zagospodarowania Kraju 2030. Dzięki takiemu podejściu przestrzeń staje się płaszczyzną odniesienia dla podejmowanych działań rozwojowych.

Najistotniejsze znaczenie dla regionalnych i lokalnych strategii rozwoju ma KSRR, określająca kluczowe cele rozwojowe dla regionów, miast i obszarów wiejskich. Porządkowanie systemu programowania to także ograniczenie liczby dokumentów strategicznych opracowywanych na szczeblu krajowym jako uszczegółowienie DSRK - w modelu założono opracowanie 9 strategii zintegrowanych.

\section{Wyzwania dla okresu programowania od roku 2014 - docelowy model programowania}

Nowy model programowania, proponowany przez Ministerstwo Rozwoju Regionalnego, jest jeszcze w budowie. Aktualnie (maj 2013) opracowane i przyjęte są jego następujące elementy:

- Długookresowa Strategia Rozwoju Kraju - Polska 2030. Trzecia fala nowoczesności, ${ }^{12}$ wraz z jej przestrzennym elementem, czyli Koncepcją przestrzennego zagospodarowania kraju $2030^{13}$,

- Średniookresowa Strategia Rozwoju Kraju, przyjęta 25 września 2012 roku przez Radę Ministrów Strategia Rozwoju Kraju 2020 - Aktywne społeczeństwo, konkurencyjna gospodarka, sprawne państwo ${ }^{14}$,

- Krajowa Strategia Rozwoju Regionalnego 2010-2020: Regiony, Miasta, Obszary wiejskie, przyjęta 13 lipca 2010 roku, czyli kompleksowy średniookresowy dokument strategiczny odnoszący się do prowadzenia polityki rozwoju społeczno-gospodarczego kraju w ujęciu wojewódzkim. ${ }^{15}$

Z pozostałych zintegrowanych strategii obecnie obowiązuje: Strategia rozwoju transportu do 2020 r. (z perspektywą do 2030 r.) ${ }^{16}$ Strategia Bezpieczeństwa Narodowego Rzeczypospolitej Polskiej 2022, ${ }^{17}$ Strategie innowacyjności i efektywności gospodarki Dynamiczna Polska 2020, ${ }^{18}$ Strategia Zrównoważonego Rozwoju Wsi i Rolnictwa, ${ }^{19}$ Strategia Sprawne Państwo 2020. ${ }^{20}$

Monitor Polski 2013, poz. 121.

www.mrr.gov.pl/rozwoj_regionalny/Polityka_przestrzenna/KPZK/Aktualnosci/Documents/KPZK2030.pdf

Monitor Polski 2012, poz. 882.

www.mrr.gov.pl/aktualnosci/polityka_rozwoju/Documents/KSRR_13_07_2010.pdf

http://www.transport.gov.pl/files/0/1795904/130122SRTnaRM.pdf

http://www.mon.gov.pl/pliki/File/strategia_obronnosci/SRSBN_RP_przyjeta090413.pdf

Monitor Polski 2013, poz. 73.

Monitor Polski 2012, poz. 839.

Monitor Polski 2013, poz. 136. 
W końcowych fazach przygotowania znajdują się ponadto strategie: Bezpieczeństwo Energetyczne i Środowisko, Strategia Rozwoju Kapitału Społecznego oraz Strategia Rozwoju Zasobów Ludzkich.

Należy więc uznać, iż dobiega końca budowa systemu programowania w skali kraju, który został wyznaczony w roku 2009. Równocześnie w skali regionalnej powstały lub powstają nowe, zaktualizowane strategie rozwoju zgodne $\mathrm{z}$ dokumentami krajowymi i UE. Powstają także i regionalne (wojewódzkie) Plany zagospodarowania przestrzennego, kreujące lad przestrzenny w regionach. Także w skali lokalnej opracowywane są (lub będą w perspektywie najbliższych dwóch lat) nowe dokumenty strategiczne uwzględniające wyzwania kolejnego okresu programowania.

Zarówno w skali kraju, regionu, jak i lokalnej wskazać można kilka wyzwań związanych z nowym podejściem do programowania. Należy do nich z pewnością:

- uporządkowanie systemu dokumentów o znaczeniu strategicznym obowiązujących w skali kraju, co w praktyce oznacza dokładne wytyczne dla strategii lokalnych, do jakich dokumentów wyższego szczebla powinny się odnosić i z jakimi dokumentami powinny być koherentne,

- wskazanie czterech szczebli programowania z przypisaniem im horyzontów czasowych. Dla strategii lokalnych najistotniejsza jest ŚSRK i KSRR, wyznaczające aktualny horyzont dokumentów regionalnych i lokalnych na rok 2020 ,

- podejście zintegrowane, zakładające współdziałanie wielu podmiotów w planowaniu i wdrażaniu polityki rozwoju oraz wielopoziomowe zarządzanie,

- wymiar terytorialny polityki rozwoju, co szczególnie w skali lokalnej w praktyce oznacza potrzebę głębszej niż dotychczas korelacji polityki przestrzennej i planowania strategicznego,

- proponuje się wprowadzenie ewaluacji, w tym ewaluacji strategii jako stałego narzędzia oceny skuteczności i efektywności działań publicznych - jako podstawy dobrego rządzenia.

\section{Podsumowanie}

Nowy okres programowania (lata 2014-2020) charakteryzować będzie w warunkach polskich uporządkowanie dokumentów strategicznych ze względu na hierarchiczność i koherentność. Uznane za istotne w dokumentach krajowych cele rozwoju realizowane będą przez strategie niższego szczebla. Co istotne, w tym okresie realizowane będzie programowanie rozwoju społeczno-gospodarczego osadzone przestrzennie, poprzez koherencje DSRK i KPZK. Struktury przestrzenne stają się więc nie mniej istotne niż granice administracyjne, gdyż dla rozwiązywania wielu 
problemów społeczno-gospodarczych przewiduje się opracowywanie zintegrowanych strategii. Pierwsze przykłady takich strategii można już wskazać (np. dla aglomeracji poznańskiej), trwają prace nad delimitacją obszarów, dla których korzystne będzie wspólne opracowywanie strategii. W obecnym systemie formalno-prawnym przygotowanie dokumentów zintegrowanych dla obszarów funkcjonalnych opiera się na dobrowolnej, celowej współpracy, co zdaniem autorki sprzyja wdrożeniu rozwoju zrównoważonego, ale może rodzić także potencjalne konflikty i trudności wynikające z: braku dotychczasowych doświadczeń współpracy czy problemów związanych z wyłonieniem lidera. Należy pamiętać, iż strategia to ciągle (w skali lokalnej) dokument opracowywany fakultatywnie, choć trudno skutecznie zarządzać rozwojem lokalnym bez posiadania strategii.

Podsumowując należy stwierdzić, że proponowane na lata 2014-2020 podejście do programowania rozwoju sprzyjać powinno wdrażaniu rozwoju zrównoważonego, poprzez promowanie współpracy i przestrzenny wymiar rozwiązywania problemów społeczno-gospodarczych, szczególnie na obszarach funkcjonalnych. 
THE REGIONAL AND LOCAL SCALE PROGRAMMING - EXPERIENCES AND CHALLENGES IN VIEW OF THE NEW PROGRAMMING PERIOD 2014-2020 AND THE RIO+20 CONFERENCE

Key words: programming of sustainable development, development policy, strategy

The article indicates how approach to regional and local development programming has been changed during the last 20 years, particularly in connection with the EU accession. In addition, it presents an attempt of assessment how a comprehensive dimension of sustainable development concept is taken into account in the development planning. In the last part of the article one can find information about the current shape of the system of strategic development management in Poland and the challenges related to the implementation of sustainable development in the new programming period. 